\title{
TRADUÇÃO COMENTADA DO POEMA “DEBUSSY”, DE MANUEL BANDEIRA, PARA A LÍNGUA BRASILEIRA DE SINAIS
}

\author{
ANNOTATED TRANSLATION OF MANUEL BANDEIRA'S POEM \\ "DEBUSSY" TO BRAZILIAN SIGN LANGUAGE
}

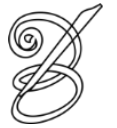 \\ Saionara Figueiredo SANTOS ${ }^{\mathrm{i}}$ \\ Doutoranda em Estudos da Tradução (UFSC) \\ Professora da área de Tradução \\ Instituto Federal do Santa Catarina \\ Palhoça, Santa Catarina, Brasil \\ saionara.figueiredo@gmail.com
}

Resumo: Este artigo deseja avançar no campo da pesquisa em tradução de poesias para a Língua de Brasileira de Sinais, Libras. A partir dos estudos iniciais e metodologia de Nicoloso (2010), cujo artigo se centraliza em sua experiência tradutória de um poema da Língua de Sinais Britânica (BSL) para a Língua Portuguesa escrita, neste artigo, expõe-se a experiência tradutória do poema na língua portuguesa "Debussy", de Manuel Bandeira para a Língua Brasileira de Sinais. Assim como o estudo da autora citada, este artigo visa enfatizar o posicionamento e as dificuldades do tradutor no processo de tradução, bem como expor uma metodologia flexível de tradução que envolvam línguas de sinais.

Palavras-chave: Metodologia de tradução. Poesia. Língua de Sinais.

Abstract: This research wants to expand reflection and discurssion on the translation of poetry for the Brazilian Sign Language, Libras. Nicoloso (2010), whose article focuses on its translational experience of a poem of British Sign Language (BSL) to the written Portuguese. So, this article exposed to translational experience of the poem in Portuguese "Debussy" by Manuel Bandeira for the Brazilian Sign Language. As Nicoloso (2008) said, this article seeks to emphasize the ositioning and the difficulties of the translator in the translation process, as well as exposing a flexible methodology of translation involving sign language.

Keywords Translation methodology. Poetry. Sign language.

\section{Introdução}

om o passar dos anos e lutas na história da educação de surdos ${ }^{\mathrm{ii}}$, os tradutores e intérpretes de língua de sinais vêm conquistando seu espaço dentro da comunidade surda. Seu trabalho vem sendo visado e paulatinamente, mais valorizado. Nesse sentido, a Lei 10.436/2002, regulamentada pelo Decreto 5625/2005, reconhece a

Língua Brasileira de Sinais (Libras) como meio de comunicação próprio dos surdos; define a qualificação deste profissional, suas possibilidades de aperfeiçoamento profissional e campus de atuação, proporcionando autonomia e acessibilidade aos sujeitos surdos. Além disso, a partir dessas legislações e com novas pesquisas voltadas às línguas de sinaisiii, o status de língua 
passível de ser vertida para outra (língua alvo), com o mesmo discurso claro da língua fonte, vêm sendo relacionado às línguas de sinais e assim, melhor compreendido através de novas pesquisas na área da Tradução.

Assim, a partir desse estopim, novas discussões sobre a tradução se desenvolveram, principalmente pelos surdos estarem ocupando novas posições na sociedade. O tradutor precisa dominar a complexidade do processo tradutório, já que essa variedade complexa das línguas de sinais permite inúmeras opções gramaticais, lexicais e morfológicas que permeiam esse processo e apontam espaços de intenso debate e reflexão (NICOLOSO, 2010).

Sobre a Língua de Sinais, cabe ressaltar que esta é uma língua que se configura através da perspectiva visual e corporal e somente esse aspecto já demonstra os desafios presentes numa tradução sinalizada. iv

No Brasil, o número reduzido de estudos e pesquisas que abordem a tradução de poesias em língua portuguesa para a língua de sinais, incluindo os intérpretes que fazem este trabalho, determina a necessidade de novas investigações voltadas a este campo. ${ }^{v}$ Esse número é modesto, já que o registro dessa tradução seria feito por meio de filmagem. A propagação de vídeos de 94 maneira contínua ainda é um processo recente; consequentemente, nem todas as traduções estavam acessíveis há alguns anos.

Entretanto, é costumeiro encontrar a afirmação de que é impossível ou difícil traduzir poesias para qualquer língua, inclusive para a Língua de Sinais, já como a modalidade das duas línguas em questão (línguas orais e línguas sinalizadas) são diferentes.

\footnotetext{
Reconhecemos que traduzir histórias (...) pode apresentar diferentes possibilidades. Realizamos a tradução de histórias da Libras para o português, quando necessário, pautados em uma tradução cultural. A convergência é improvável e, talvez, indesejável. Enfim, suscetíveis à contradição, à heterogeneidade e à multiplicidade, coletamos materiais que compõem uma colcha de histórias e de sinais que conversam entre si em tom de disputa, dissonância, apoio, diálogo, contenda e/ou contradição. (KARNOPP, 2013, p. 411)
}

Essa tarefa exige profunda sensibilidade, tal qual um poeta possui. Há preocupações relacionadas à estética, "ao expor predileções e rejeições, põe as paixões a nu” (NICOLOSO, 2010, p.309). Assim, esse artigo traz a experiência comentada de tradução de um poema em Língua Portuguesa, "Debussy”, de Manuel Bandeira, vertido para a Língua Brasileira de Sinais (Libras). Essa tentativa envolveu duas línguas de modalidades diferentes, além de duas culturas distintas, o que é compreensível no processo de tradução, não sendo essa uma tarefa simples ${ }^{\mathrm{vi}}$. 


\section{Sobre a tradução de poesia}

Quando se fala em traduzir poesia, é frequente a abordagem da intraduzibilidade. Entretanto, Steiner (2005) traz o posicionamento de Jakobson ao reforçar que a "transposição criativa" somente é possível dentro da mesma língua de uma língua para outra ou entre meios e códigos expressivos bastante diferentes" (STEINER, 2005, p. 283). A poesia requer um trabalho impecável, já que a mesma envolve linguagem, forma, métrica, aspectos estéticos, além de escolhas tradutórias que envolvam as línguas fonte e alvo.

Klamt (2014), ao fazer uma pesquisa bibliográfica, traz os estudos de Laranjeira (2003), que corroboram com Steiner (2005), ao falar da relação tênue da entre língua e poesia. Nesse sentido, a língua deixa de ser código, deixa de ser apenas um suporte, um veículo para fazer parte integrante da própria mensagem. O significante ganha terreno sobre o significado, prepondera sobre ele, gera-o" (LARANJEIRA, 2003, p. 21).

Na poesia, forma e conteúdo estão entrelaçados. Assim, a tradução de uma poesia precisa corresponder ao original nos mais variados níveis (CONNOLLY, 2000, p. 172). Deve ser um trabalho operado nos mais diversos níveis (semântico, linguístico e estrutural) integrados todos no nível semiótico-textual [...]” (LARANJEIRA, 1993, 125).

Guerini (2000) complementa que na tradução de poesia a forma, a mensagem, a estética é primordial e não apenas aspectos semânticos. Assim, a tradução é a produção de um texto original, sendo necessário "traduzir o perfil sensível da mensagem, a forma”. (GUERINI, 2000, p. 109).

Desde 1813, Schleiermacher já assinalava que a tradução de poesia muitas vezes se perde, devido à divergência de ritmo nos resultados finais. Klamt (2014) comenta o trabalho de Heidermann (2010) que trouxe as contribuições de Scheleiermacher sobre o ritmo e entonação, partes importantes da poesia e que devem estar presentes em sua respectiva tradução, para que o encanto proporcionado por ela não seja descuidado. Costa \& Guerini (2006) assinalam sobre a evolução da traduzibilidade da poesia, ao dizer que:

[...] a tradução de poesia se transformou em uma arte bastante sofisticada, e podemos dizer que a qualidade média da tradução poética entre nós supera a da prosa, reputada mais fácil. Isso talvez se deva ao fato de que os tradutores de poesia parecem muito mais conscientes dos problemas da tarefa que seus congêneres de prosa, justamente porque a tradução de poesia tem sido sistematicamente discutida entre nós nas últimas décadas (COSTA \& GUERINI, 2006, não paginado). 
Para Laranjeira (2003), o tradutor não deve se sentir preso à forma ou aos parâmetros linguísticos e literários a tal ponto onde não consiga traduzir. $\mathrm{O}$ autor acredita na traduzibilidade da poesia. $\mathrm{O}$ tradutor não pode ser ter como meta manter exatamente tudo linguisticamente e poeticamente do original. "Cabe-lhe, entretanto, expandir ao máximo o limite das fidelidades e, pela inventividade de seu gênio, recuperar e compensar possíveis perdas de trajeto nos diversos níveis" (LARANJEIRA, 2003, p. 129).

Laranjeira (2003) também elucida sobre as fidelidades que deve coexistir na tradução de um texto poético. A fidelidade semântica é a primeira a ser considerada, já que envolve o sentido a ser comunicado. Normalmente, há desvios do nível semântico para que o nível poético permaneça inalterado. A fidelidade linguístico-estrutural pressupõe a manutenção dos níveis sintáticos e prosódicos de todas as classes gramaticais. Nesse sentido, Queiroz (2006) explica que a tradução obedece às marcações e os devaneios do original, preservando os paralelismos sintáticos e a perfeição poética. Além disso, Laranjeira (2003) complementa que a fidelidade semiótico-textual incorpora todas as fidelidades, dando identidade poética do original à tradução.

Outra questão é sobre a responsabilidade do tradutor na tradução de poesias. Alguns pensam que um poeta seria o melhor tradutor para uma poesia, já que não são questões meramente linguísticas envolvidas no processo, embora se considere importante conhecer de poesia nos dois idiomas para legitimar a tradução. Basnett (2003 p. 105) cita as palavras de Dryden, quando este fala que o tradutor precisa conhecer as características do "espírito" do autor original, além das peculiaridades culturais e da época. Nem todos concordam com essa afirmação, incluindo Weininger (2012), que disserta que a equivalência é um parâmetro de pressão, que prejudica a traduzibilidade de uma poesia, onde essa equivalência se torna “inexorável e inalcançável, desejo mais árduo, tormenta e frustração extremada, igualando o tradutor ao próprio poeta, em certo sentido" (WEININGER, 2012, p. 194), já como há imposições estéticas fixas. Klamt (2014) complementa que:

(...) os mitos não se sustentam, pois: os textos não são construídos do vazio, todo texto é fruto de intertextualidade (mito do autor genial); é impossível saber as intenções do autor quando escreveu um texto, nem mesmo quando o autor fala sobre elas (mito da intenção do autor); é difícil, se não impossível saber o significado do texto, já que ele se modifica no tempo e de acordo com a recepção (mito do significado do texto original); o tradutor não é um robô subalterno nem um gênio cosmopolita. (KLAMT, 2014, p. 109) 
Sobre a manutenção dos efeitos sonoros e rítmicos do poema no texto de chegada, o autor discorre que, mesmo quando não há rima, há efeitos sonoros como por exemplo "assonâncias, repetição ou alternância de determinadas vogais e consoantes, sequência ou alternância de palavras curtas ou longas, com determinada acentuação, mesmo onde não há uma métrica fixa." (WEININGER, 2012, p. 210). Analisar a distribuição desses efeitos antes de se realizar a tradução permite que a forma e a sonoridade se elevem a um patamar onde antes só estava o aspecto semântico.

Klamt (2014) ainda assinala que Laranjeira defende que a ideia do texto de partida deve permanecer no texto de chegada, mantendo "uma relação semelhante a nível de significantes e não apenas lançar mão do assunto do original e adicionar-lhe a forma” (KLAMT, 2014, p. 110), trabalhando a língua alvo. Ou seja, o sentido está intrínseco à poeticidade, numa relação similar de significantes em ambos os textos envolvidos na tradução, não podendo um texto "lançar mão de um assunto - um fundo - e poetizá-lo simplesmente acrescentando-lhe apêndices formais como métrica, rima etc" (LARANJEIRA, 2003, p. 29-30).

Como a tradução envolve duas línguas-culturas diferentes, muitas vezes o tradutor se vê em posicionamento dúbio, onde pode estrangeirizar o texto, se mantendo fiel ao contexto da língua fonte, ou domesticá-lo, fazendo adaptações para torná-lo costumeiro. O tradutor se encontra em dúvida, compartilhada por Klamt (2014) nas palavras de Steiner (2005):

Deveria uma boa tradução amoldar sua língua em direção daquela do original, criando assim uma aura deliberada de estranhamento, de opacidade periférica? Ou deveria naturalizar o caráter da importação linguística de modo a torná-la familiar na língua do tradutor e de seus leitores? (STEINER 2005, p. 287)

Sendo assim, Schleiermacher (2010), corrobora com Steiner (2005), quando afirma que "Ou bem o tradutor deixa o escritor o mais tranquilo possível e faz com que o leitor vá ao seu encontro, ou bem deixa o mais tranquilo possível o leitor e faz com que o escritor vá ao seu encontro"(p. 57). O descentramento da tradução elimina o foco apenas um processo linguístico, mas cultural. No caso deste trabalho, a tradução é feita a partir de duas línguas usadas no Brasil (embora a Língua Portuguesa seja mais conhecida do que a Libras e estas tenham aspectos tão distintos); nesse sentido, o tradutor encontra um dilema: estrangeirizar o poema, optando por escolhas lexicais e contextuais que sejam específicas da língua de sinais e que nem todos os ouvintes falantes do Português entenderão; ou domesticar o poema, fazendo que ele tenha aderência literária e que possa perder algumas propriedades literárias? Nesta tradução literária, optou-se por equilibrar ambos os aspectos, para que a poesia não perdesse suas características 
de língua original, bem como fosse culturalmente adaptada à Língua Brasileira de Sinais.

Com essa pergunta em mente, passa-se a dissertar sobre o contexto da traduzibilidade voltada à Língua de Sinais.

\section{Sobre a tradução de poesia para a Língua de Sinais}

Em primeiro lugar, é necessário reconhecer o patamar de língua já dado à Língua Brasileira de Sinais (Libras). No Brasil, houve muitas conquistas da comunidade surda, principalmente com a oficialização da Libras e da cultura surda pela Lei 10.436/2002 e, posteriormente, regulamentada pelo decreto 5.626/2005. A comunidade surda ${ }^{\mathrm{vii}}$ sempre buscou criar estratégias discursivas para se diferenciar dos sujeitos "com necessidades especiais", além de demarcar sua diferença linguística e cultural.

A própria profissão de Tradutor e Intérprete de língua de sinais (TILS) ganha amparo legal a partir das legislações acima citadas e é regulamentada em 2010, pela lei 12.319, que inclui formação necessária e áreas de atuação. A partir dessa lei, também decorrente da intensa luta dos surdos pela acessibilidade nos mais diversos espaços (principalmente no educacional),

98 a valorização do profissional é impulsionada, estimulando o aperfeiçoamento e a qualificação (NICOLOSO, 2010). Em todo o Brasil, há associações de TILS que se interessam em aprofundar as discussões sobre o ato interpretativo e ética profissional, além do incentivo à pesquisa e valorização também da área dos Estudos da Tradução e da Interpretação voltados à Libras.

Apesar das mudanças expressivas na legislação e nas produções culturais e científicas de algumas instituições, os surdos continuam a lutar por sua diferença linguística e cultural, "não somente nos espaços escolares, mas também na mídia e nos diferentes artefatos culturais" (KARNOPP, 2013, p. 408). Nesse sentido, as produções culturais surdas ${ }^{\text {viii }}$ - ou em língua de sinais (a partir de traduções) - infundem significados na construção de identidades, diferenças e valorização da língua. Esses artefatos "convergem para o entendimento dessa comunidade como um grupo cultural e como uma minoria linguística” (KARNOPP, 2013, P. 408).

Com essa contextualização realizada no que tange à língua de sinais, cultura surda e todos os aspectos que envolvem uma tradução que envolvam duas línguas e culturas diferentes, percebe-se que fazer uma tradução de poesias da/para a língua de sinais não é um trabalho simples.

Alguns autores reforçam que as tentativas de se traduzir poesias (em par linguístico) deixam margem para erros de tradução. Souza (2009) explica que essa noção de traduzibilidade 
precisa ser levada em conta em cada contexto tradutório, onde os dois textos (o original e a tradução) precisam estar conectados, como um "ato performático" (p. 319). A Língua de Sinais entra também nesse contexto. Ele continua:

\begin{abstract}
Não podemos deixar de ter consciência de que o texto poético trabalha com a linguagem em todos os seus níveis - semânticos, sintáticos, fonéticos, rítmicos, entre outros. Nesse sentido, mesmo havendo perdas em nível de modalidade de enunciação e articulação, a traduzibilidade poética também pode ocorrer no âmbito da Libras, favorecendo esboços e contribuições tradutórias gráfico-visuais na Língua Portuguesa (SOUZA, 2009, p. 319)
\end{abstract}

Laranjeira (2003) afirma que quando duas línguas/culturas não possuem uma base gráfica comum, haverá dificuldades de tradutibilidade quanto à visilegibilidade. Klamt (2014) também reforçou que, em relação às línguas envolvidas neste tipo de tradução - o que é um ponto significativo para o presente trabalho, são duas línguas de modalidades e suportes de registro bastante distintos. ${ }^{\text {ix }}$ Em seu trabalho traduzindo "Vôo sobre Rio" da poeta surda Fernanda Machado da Libras para a Língua Portuguesa, ele citou os conceitos de visilegibilidade de Laranjeira (2003), ou seja “[...] pré-leitura visual, baseada na distribuição espacial da massa textual, gráfica, do poema. [...] Antes de ler o poema, o leitor vê o poema e esta visão já condiciona as leituras que se darão posteriormente". A visilegibilidade de um poema em português ocorre em formato escrito, ao contrário de sua tradução, que necessita um suporte visual (vídeos), o que implica uma grande mudança de formato para que a tradução consiga ser realizada. (KLAMT, 2014). Laranjeira (2003) ainda complementa que a "homogeneidade espacial-visual só poderá ser mantida por meio de artifícios, ou terá de ser simplesmente abandonada, ficando a transposição da significância por conta apenas de outros elementos" (LARANJEIRA, 2003, p. 104).

Com tais princípios em mente, além do equilíbrio entre a domesticação e a estrangeirização, aceitou-se o desafio, feito em uma disciplina especial de doutorado em Estudos da Tradução, de fazer uma tradução de um texto poético de Língua Portuguesa para a Língua de Sinais. Como já relatado acima, este artigo consiste em uma tradução comentada do poema "Debussy” de Manuel Bandeira em Língua Portuguesa para a Libras.

Usa-se a metodologia que NICOLOSO (2010) utilizou em sua tradução, utilizando a abordagem qualitativa de Triviños (1987), que afirma que a mesma:

[...] baseia suas conclusões nas descrições do real cultural que lhe interessa para tirar delas os significados que têm para as pessoas que pertencem a essa realidade. Isso obriga os sujeitos e o investigador a uma participação ativa onde se compartilham 
modos culturais [...]. Isto é, em outros termos, o pesquisador não fica fora da realidade que estuda, à margem dela, dos fenômenos aos quais procura captar seus significados e compreender (TRIVIÑOS, 1987, p. 121).

Houve o cuidado de respeitar os contextos históricos, o estilo de escrita e visual espacial de cada língua (portuguesa e Libras, respectivamente), e culturas das duas línguas, além das diferenças linguísticas, mantendo a proximidade das duas culturas e o estilo, já que a sensibilidade é necessária para inserir expressões faciais, corporais e linguísticas no contexto tradutório.

Sutton-Spence $(2005,2012)$ disserta sobre a poética das línguas de sinais, ao afirmar que é uma expressão da estilística sinalizada, onde a língua é fundamental na mensagem, configurando-se numa construção cultural. Juntamente com jogos tradicionais, piadas, com o folclore surdo, as poesias sinalizadas podem se utilizar criativamente da variação de movimentos e de configurações de mão para indicar drama, humor ou intensidade.

Para as escolhas tradutórias da língua-alvo (Libras), levou-se em conta os parâmetros da poesia em língua de sinais, aprofundados por Quadros e Sutton-Spence (2006), que 100 descrevem "a forma intensificada de linguagem ("sinal-arte") para efeito estético" (QUADROS E SUTTON-SPENCE 2006, p.112). Esse "sinal-arte" seria o sinal que se usa para construir a peça poética, ou seja, não são apenas escolhas lexicais da Libras: são formas diferentes escolhidas para o momento da poesia, diferenciações feitas no movimento ou na configuração de mão, intensificações, que permitam aos sinais um aprofundamento artístico (SILVA, 2012).

Para a realização desta pesquisa, estudou-se o texto de partida, analisando a intenção do texto, a linguagem, com o intuito de se manter a coesão textual. A forma de registro escolhida foi a filmagem, em virtude da língua alvo ser viso-espacial (Libras). No texto de chegada, privilegiou-se o contexto cultural, analisando as tentativas de produzir efeitos poéticos na tradução do poema. O texto escolhido - "Debussy" de Manuel Bandeira, foi escolhido em virtude de se manifestar claramente efeitos visuais, favorecendo as escolhas tradutórias. Algumas decisões tradutórias foram necessárias, assim como NICOLOSO (2010) em sua pesquisa. A pesquisadora fez o processo inverso (traduziu um poema da Língua de Sinais para a Língua Portuguesa); porém seus parâmetros se aplicam a esta pesquisa. São:

(i) preservar a intencionalidade do autor e a função do texto como fator intratextual, (ii) adaptar os elementos do texto de partida para o texto de chegada, levando em consideração a diferença de modalidade das línguas facilitando a compreensão do público alvo e, por último, (iii) utilizar uma tradução domesticante e não exorcizante, pois se pretende manter a forma como o poema retrata $[\ldots]$ as informações, a intenção 
Por conveniência, segue a apresentação do poema em Língua Portuguesa, para melhor entendimento das escolhas feitas durante sua tradução.

\section{4. "Debussy", de Manuel Bandeira}

Para cá, para lá...

Para cá, para lá...

Um novelozinho de linha...

Para cá, para lá...

Para cá, para lá...

Oscila no ar pela mão de uma criança

(Vem e vai...)

Que delicadamente e quase a adormecer o balança

- Psiu... -

Para cá, para lá...

Para cá e...

- O novelozinho caiu.

\section{Comentários sobre o processo de tradução do poema "Debussy"}

A princípio, observou-se várias vezes o poema em Língua Portuguesa, para apropriação do texto e da mensagem; alguns fatores foram levados em conta como: contexto do autor ao escrever, questões culturais de cada língua, jogo de palavras, (todos estes para entender e traduzir, por exemplo, a musicalidade da escolha de palavras do autor do poema fonte), informações presentes neste texto para se entender o contexto condicionado. $O$ primeiro passo foi realizar uma tradução literal, pensando um sinal para cada palavra em português, adequando o estilo e a intencionalidade do poeta, assim como a função do texto. A partir desse primeiro texto, pensou-se em adequar os elementos escolhidos na tradução para a modalidade de poesia da Libras, facilitando a compreensão do público-alvo. A intenção e o contexto da cultura fonte, além das informações do poema foram mantidos (o sujeito principal do poema, o movimento do novelo, a musicalidade do poema, por exemplo), equilibrando a domesticação da tradução e a estrangeirização já mencionados.

Em suma, em todas as etapas desta tradução, alguns fatores foram levados em consideração para a finalização desta tradução: a origem e a cultura do autor (Manuel Bandeira); 
o tempo da comunicação em sinais e a harmonização da versão escrita; movimento do corpo, mãos e olhar, relacionando à rima e à pontuação; o uso de expressões faciais e classificadores; o jogo de palavras em português usadas pelo autor, além da escolha do léxico em Libras para a compreensão do público. As maiores dificuldades foram transformar a linguagem poética num contexto em Libras também artístico, transmitir a sonoridade do poema na Libras, escolher a pessoa e a forma de narração, monitorar a tradução e a competência do tradutor, além de colocar elementos que caracterizassem o texto alvo para o gênero literário.

\section{Debussy: Primeira versão}

A primeira versão foi mais literal, numa aproximação de palavras para os sinais escolhidos, para tentar capturar as intenções do poeta. Abaixo, traz-se a glosa ${ }^{\mathrm{x}}$ da primeira e automática tentativa de tradução, sem inserção no meio poético da Libras, apenas no lexical, com o intuito de entender a cerne do poema.

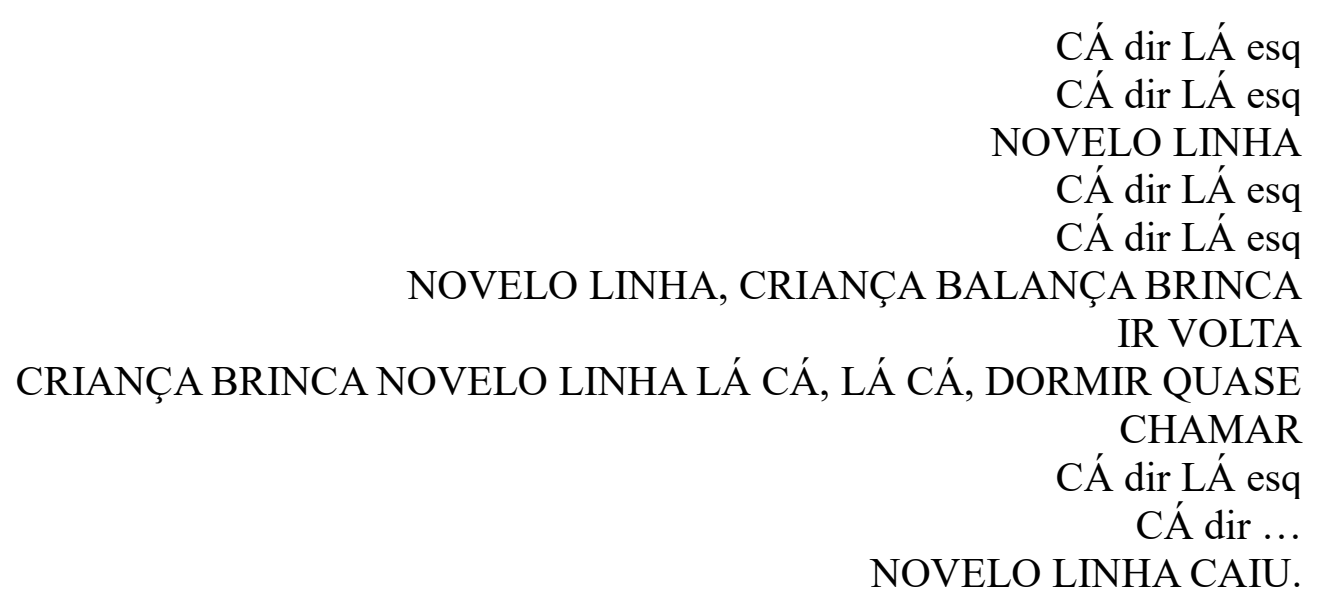

Porém, fez-se necessário fazer, a partir da versão acima, uma pesquisa sobre a origem do poema foi feita com o intuito de perceber o contexto no qual o poema estava inserido, já que o texto foi compreendido. Nesse sentido, fez-se uma pesquisa teórica com o fim de compreender a relação do poema com seu contexto histórico, para que o processo tradutório se complementasse.

Os poemas Debussy e Epílogo, de Manuel Bandeira, foram poemas escolhidos do livro Carnaval, publicado em 1919. Manuel Bandeira começara a se corresponder com Mário de Andrade após a Semana de Arte Moderna, oferecendo a ele um exemplar deste livro. Míccolis (2005) complementa que: 
"Debussy" e "Epílogo" seriam apenas dois poemas, entre diversos outros, a tratarem, direta ou indiretamente, da música na poesia. Só na obra Carnaval, dos 33 poemas, nove expressamente fazem referência à música, sendo que em sete deles ela aparece já nos títulos: A Canção das Lágrimas de Pierrot, Debussy, [...] embora, portanto, a importância da música já esteja bastante visível neste segundo livro, esse dado seria apenas mera constatação, registo sem outras conotações. Somente à luz da correspondência epistolar dos dois poetas podemos descobrir e aprofundar-nos em outros debates sociais que subjazem nestes dois poemas, valorando a importância da música como tema capaz de mobilizar outras espécies de polêmicas bem mais amplas (MICCOLIS, 2005, não paginado)

Segundo a autora acima citada, o título "Debussy" se refere ao compositor e músico francês Claude Debussy (1862-1918).

Ela despertou em Debussy um forte sentimento de independência e liberdade artística, prevendo seu futuro promissor como músico, o que o incentivou a criar sua própria linguagem: buscando inspiração nos poetas e pintores de seu tempo, "a música dele possui as cores e luzes do impressionismo, descrevendo o mundo em harmonias inovadoras para a sua época", no dizer do Novo Dicionário Grove de Instrumentos Musicais (MICCOLIS, 2005, não paginado)

Entretanto, no poema, não há nenhuma observação específica que o relacione à composição, embora a leitura e a métrica do poema, além da imagem que o mesmo nos proporcione, nos permitam perceber uma música própria. $\mathrm{O}$ menino que, com um novelo na mão, balança em um ritmo harmonioso e delicado, até adormecer.

\footnotetext{
Nada de erudição ou de pedantismo para falar de música clássica. Ele a enfoca indiretamente, através de uma forma acessível a que todos entendem da importância da própria música (outro tema muito presente na correspondência deles), que se revela, ao final, como a de trazer paz a pessoas simples e sensíveis. Uma paz que não equivale a inércia (afinal o novelozinho não pára, enquanto a criança está acordada, ativa e lúdica); mas sim a um renovar de forças para continuar a desnovelar o novelozinho de linha pra cá e pra lá, no dia seguinte (MICCOLIS, 2005, não paginado).
}

O "para cá, para lá" do poema, são os primeiros compassos da canção "Rêverie, mas à rebours", do compositor. Interessante que o autor usa um personagem simples do cotidiano (a criança que brinca com o novelo) "sem postura elitista ou didática de quem privilegiadamente "entende do assunto". No caso de Debussy, de Bandeira, ainda se manifesta outro assunto, tantas vezes encontrado na correspondência dele com Mário, que diz respeito ao modo com que a cultura estrangeira é assimilada por pessoas “comuns" - já que a música clássica é praticamente toda estrangeira - desmistificando o preconceito de que, só por não ter cultura, o povo é incapaz de gostar de música considerada "erudita". 
Por fim, outro aspecto importante do poema é a estética popular escolhida por Manuel Bandeira: preferia retratar elementos do cotidiano (uma criança a brincar com um novelo de lã) do que privilegiar o imagético elitizado, revelando também suas intenções nas escolhas dos elementos da poesia.

Assim, depois da pesquisa realizada sobre o contexto histórico do poema, passou-se a meditar em algumas dificuldades no entendimento caso se optasse em permanecer nesta primeira versão: (1) já como é uma poesia e será em Libras, alguns elementos da poesia surda precisam ser incorporados também na tradução, para que haja também tradução cultural do poema; (2) Entendendo o contexto histórico e as intenções do autor (compreendida após pesquisa), notou-se que o autor preza pela simplicidade de sentenças e de estética. Assim, essa simplicidade também necessitaria ser evidenciada nas escolhas tradutórias realizadas; (3) Nicoloso (2010, p. 323) também preocupou-se com o ato de traduzir, onde "a competência cultural e linguística do tradutor sempre é colocada à prova e, várias vezes, as dúvidas e incertezas de uma boa escolha ou opção mais adequada nos arrebatam durante esse ato", sendo também esta inquietação também da tradução de Debussy; e, finalmente, (4) pensar em que 104 escolhas tradutórias fazer a partir do texto fonte (adições e substituições por exemplo) no texto alvo.

\section{Debussy: Segunda versão}

A partir do conhecimento do contexto do poema, percebeu-se que a tradução deveria ir mais além, não somente na área lexical e linguística, mas estratégias literárias e imagéticas para tornar o poema interessante visualmente.

(Personificação - criança brincando - acha um novelo de lã)

CÁ dir LÁ esq

CÁ dir LÁ esq

NOVELO LINHA (CL)

CÁ dir LÁ esq

CÁ dir LÁ esq

NOVELO LINHA, CRIANÇA BALANÇA BRINCA (CL)

IR VOLTA

CRIANÇA BRINCA NOVELO LINHA LÁ CÁ, LÁ CÁ, DORMIR QUASE (CL)

CÁ dir LÁ esq

CÁ dir...

NOVELO LINHA CAIU, CRIANÇA DORMIU (CL) 
Nesta segunda versão, acrescenta-se alguns acréscimos, omissões e substituições de alguns elementos morfológicos e sintáticos. Preferiu-se manter as repetições, já que fazem parte da musicalidade do poema, além de, se retirados, alteram a mensagem final do mesmo. Essas repetições, a entonação das palavras (obedecida pelos classificadores e movimentações escolhidos na tradução) e o próprio sujeito do poema (a criança que brinca com o novelo) são realizados com ajuda de algumas estratégias da Libras, para dar sentido ao texto de maneira poética.

Achou-se necessário acrescentar a criança brincando no início do poema, já que esta ação fica subtendida na leitura de "Debussy”. Nesse aspecto, pensou-se em fazer classificadores durante o poema, para deixar a linguagem poética mais viva e chamativa para o leitor. O novelo de linha e a própria criança precisam ficar claros; nesse caso, optou-se por não usar o sinal de "criança" e "linha", mas usar classificadores (CL) ${ }^{\mathrm{xi}}$ e sinais livres para dar a entender esses contextos. O movimento de "lá e cá" foi feito obedecendo a canção de Debussy, inspiração para o poema. A imagem abaixo é um dos prints do vídeo contendo a tradução em Libras, demontrando os classificadores escolhidos para demonstrar que o sujeito a brincar com o novelo seria uma criança:

Figura 1 - Print do momento em que a tradutora faz um classificador, indicando que a é uma criança - ao usar o ato de brincar de carrinho, além das expressões faciais

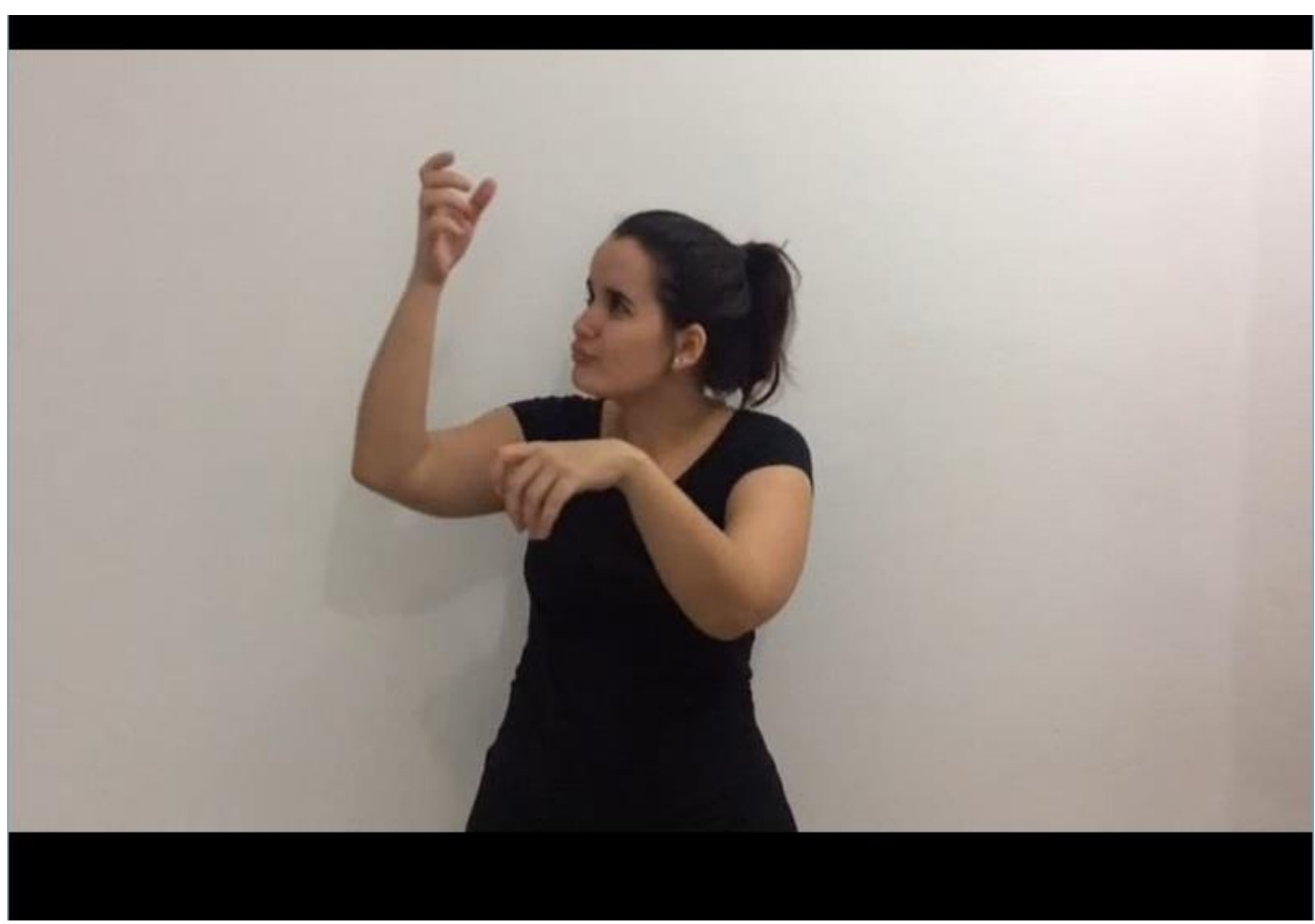


Assim, em suma, alguns elementos foram reavaliados para esta segunda versão de tradução: a origem do autor e a musicalidade do poema; os tempos verbais das ações que circundam o poema; a função lexical e textual de cada sinal e o contexto em que ele foi inserido; substituição de sinais por classificadores, com expressão corporal e facial.

Uma terceira versão foi feita, para aproximar mais os sinais escolhidos da linguagem poética da Libras. Nessa última etapa também se pensou no ritmo do poema e nos "sinais-arte", citados por Weininger, Sutton-Spence (2013, não paginado), que pensam na poesia sinalizada como uma forma de arte linguística, ou seja, um "produto textual que incorpora elementos de outras linguagens como pintura, cinema, teatro, dança e arte performativa (...) que vão além do vocabulário e da gramática convencionais".

Adiciona-se o uso de morfismos durante a transição da execução de sinais. Os parâmetros finais são similares aos parâmetros iniciais do sinal sucessor, num padrão poético "suave e elegante" (QUADROS \& SUTTON-SPENCE, 2006, p. 151). Um exemplo é a configuração de mão com dedo polegar e indicador unidos, formando um círculo, outros dedos estendidos, formando o globo ocular da criança e, após isso, também entra em transição para os movimentos 106 de para lá e para cá, indicando o movimento do olhar da criança acompanhando o novelo.

\section{Debussy: Versão final}

Nesta versão final, ao invés de se utilizar as glosas como nas outras versões acima demonstradas, preferiu-se usar prints do vídeo final da poesia. Como se trata da versão, a priori, final de tradução, pretende-se melhor demonstrar as estratégias utilizadas, bem como os sinais realizados. Estes prints em momento algum substituem a versão final, em vídeo, já que nenhuma foto de um sinal substitui sua versão dinâmica. No entanto, pensou-se fazer necessário imagens para melhor contextualizar as escolhas tradutórias, além de, por meio destas empoderar a Libras como língua alvo deste estudo.

Neste momento de finalização da tradução, a maior preocupação foi utilizar uma linguagem poética e de estética rica, expressando a vivacidade presente no poema de Bandeira. Manteve-se a estratégia de uso de incorporação para identificar o sujeito principal do poema (a criança). Alguns elementos foram acrescentados, por exemplo, demonstrar o encantamento da criança ao encontrar o novelo de lã, como a imagem abaixo demonstra: 
Figura 2 - As mãos fazem classificadores para demonstrar os olhos bem abertos e surpresos da criança.

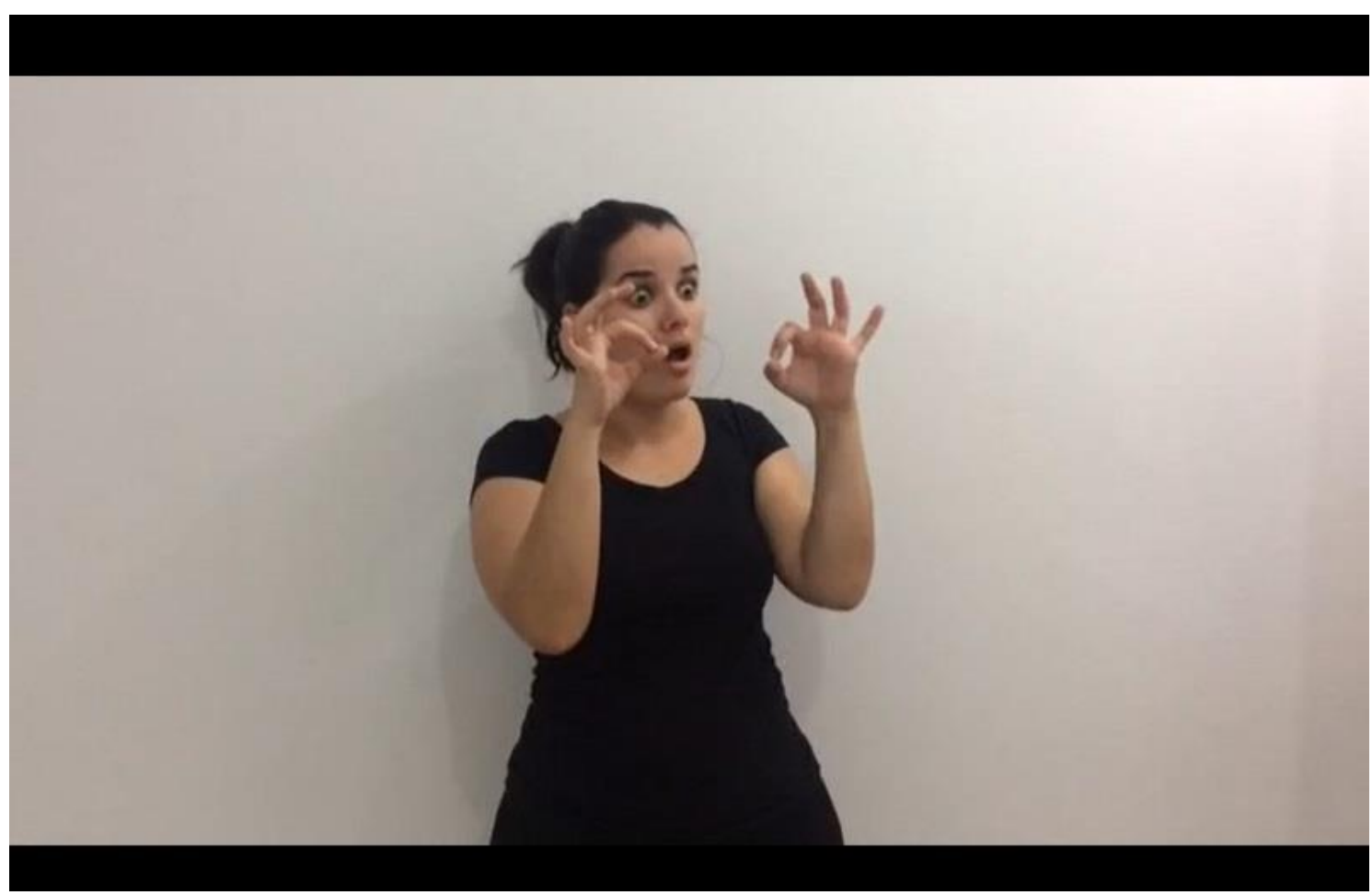

Outra escolha foi também usar classificadores para demonstrar a existência do novelo. Acrescentou-se, porém, o sinal de "tricotar", para que ficasse claro que de que tipo de linha se estava falando, além de contextualizar o movimento de "para lá, para cá". As imagens 3 e 4, mostram o classificador utilizado para "novelo" e o sinal de "tricotar", respectivamente. 


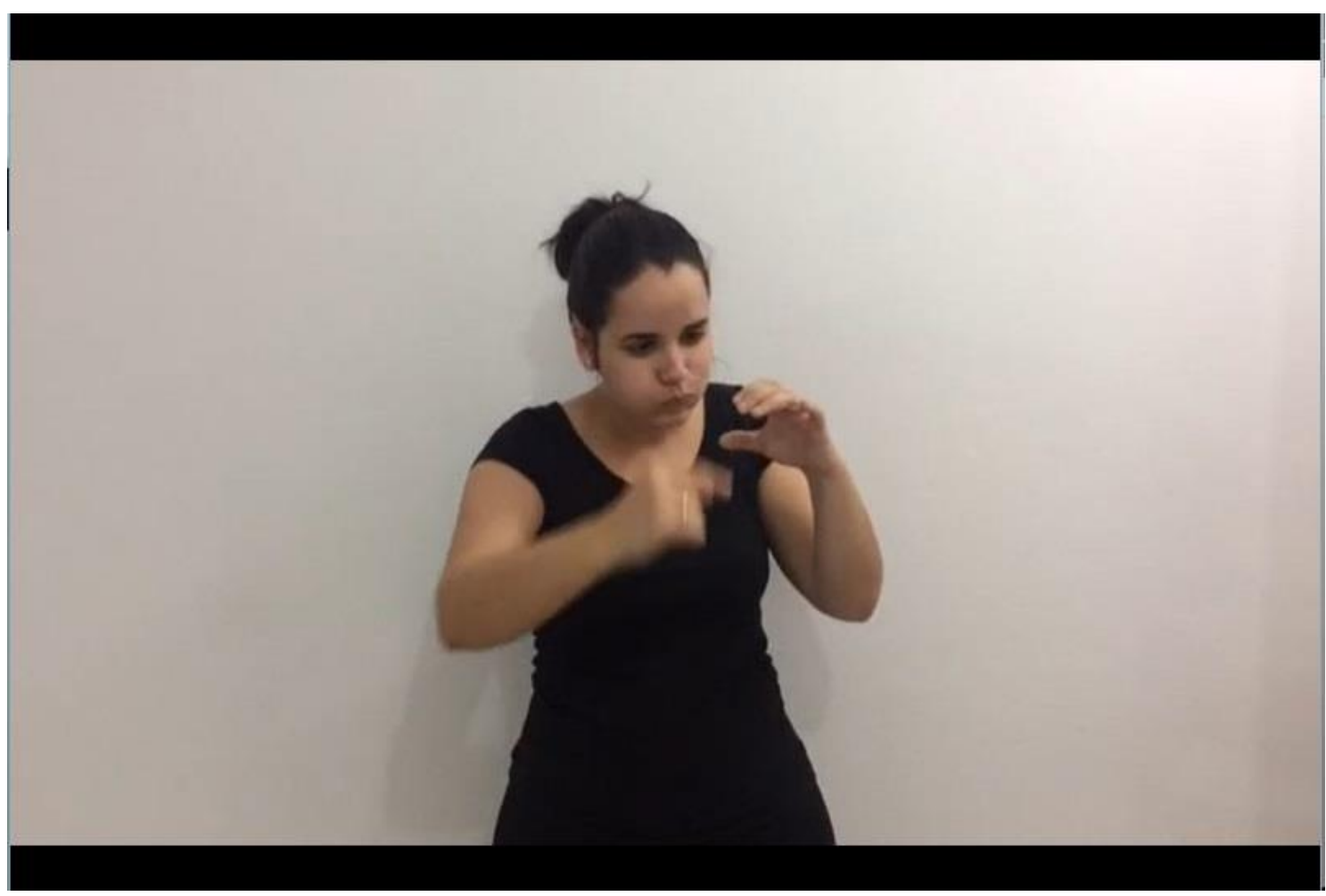

Figura 4 - Sinal de "tricotar", com movimentos dos dedos indicadores simulando o movimento das agulhas.

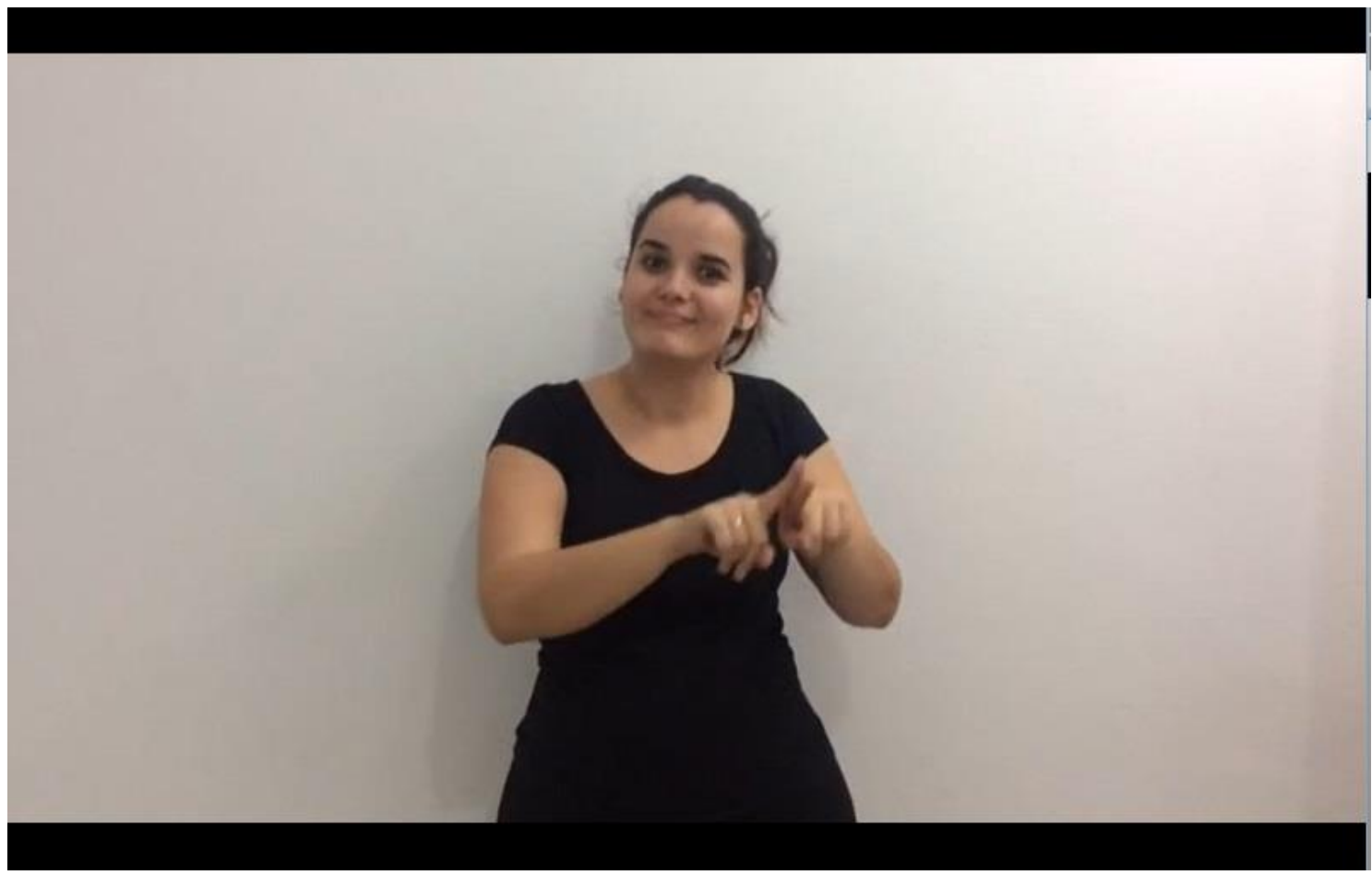

O movimento de "para lá, para cá" ficou contextualizado, já que foi realizado a partir do sinal anteriormente realizado (Classificador para "novelo"), ou seja, procurou-se dar ritmo 
entre as palavras-sinais, para manter também a métrica e ritmo da poesia.

Figura 5 - Imagem 5: Movimento de "para cá, para lá" do novelo, com mão segurando linha do novelo, e movimento da esquerda para a direita, repetido algumas vezes, indicando continuidade da ação, da brincadeira da criança.

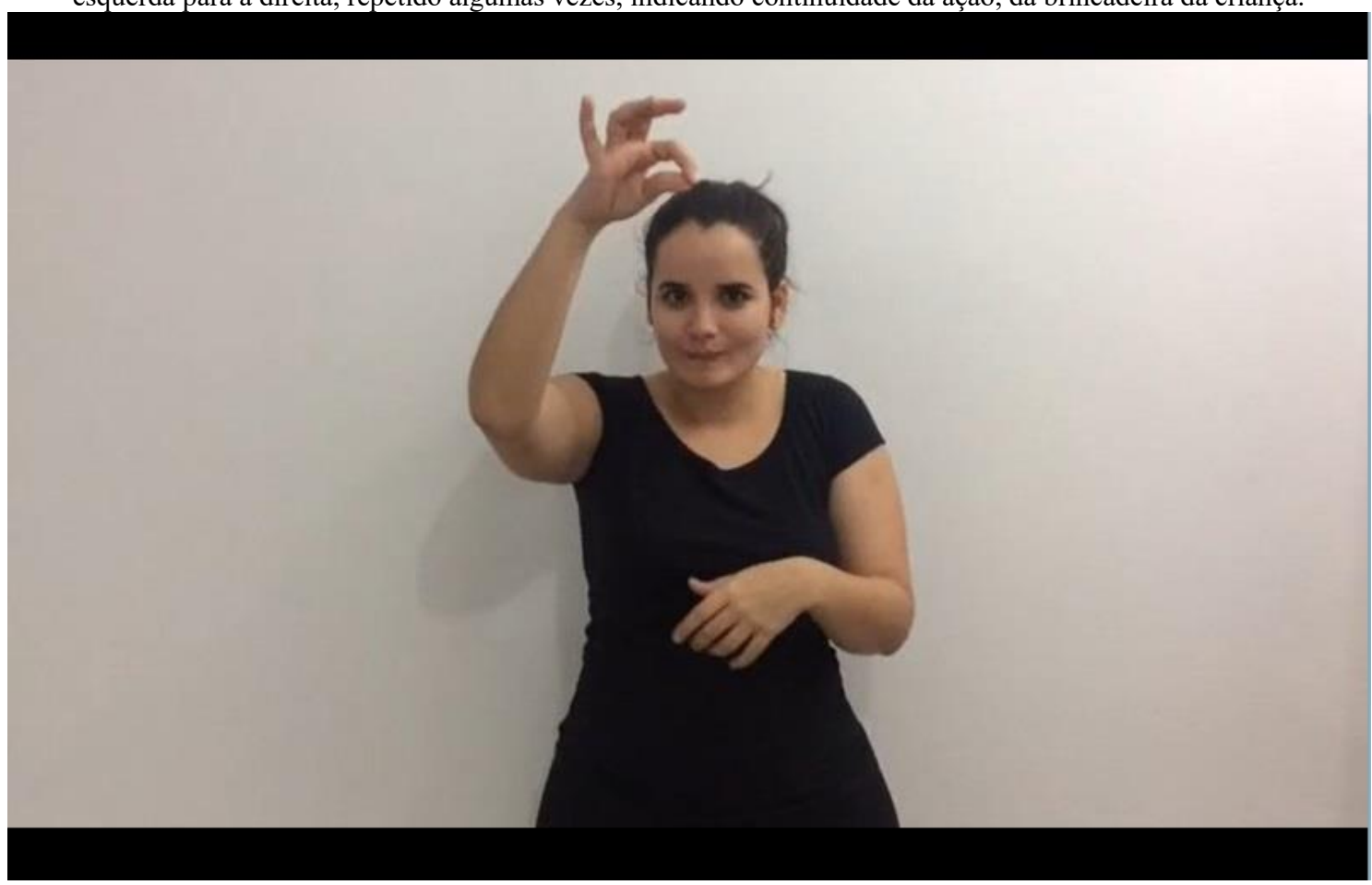

A ação da criança adormecendo enquanto brinca com o novelo também precisou ser pensada, já como é o ápice da poesia. Na poesia em Libras tentou-se demonstrar a tentativa da criança de se manter acordada, de continuar brincando, apesar da sonolência oriunda da movimentação repetitiva, do vai e vem do novelo. Assim, após demonstrar o vai e vem, o "para cá e para lá", optou-se por fazer duas vezes a repetição da brincadeira do vai e vem do novelo de lã, da criança quase dormir e resistir. Usou-se também os formatos de "olhos vivos" demonstrados na imagem os olhos anteriormente demonstrados na imagem 2, para mostrar que os olhos da criança seguiam o movimento do novelo.

O formato redondo dado pelos dedos precisou ir se estreitando, de acordo com a sonolência da criança, assim como o movimento de "para lá, para cá" também teve sua velocidade diminuída conforme a sonolência da criança vai ficando mais forte. 
Figura 6 - Imagem 6: Movimento de olhos da criança, no momento que o novelo de lã vai "para lá", sendo, portanto, o movimento de "para cá", o movimento dessas mesmas mãos para o lado direito e assim por diante.

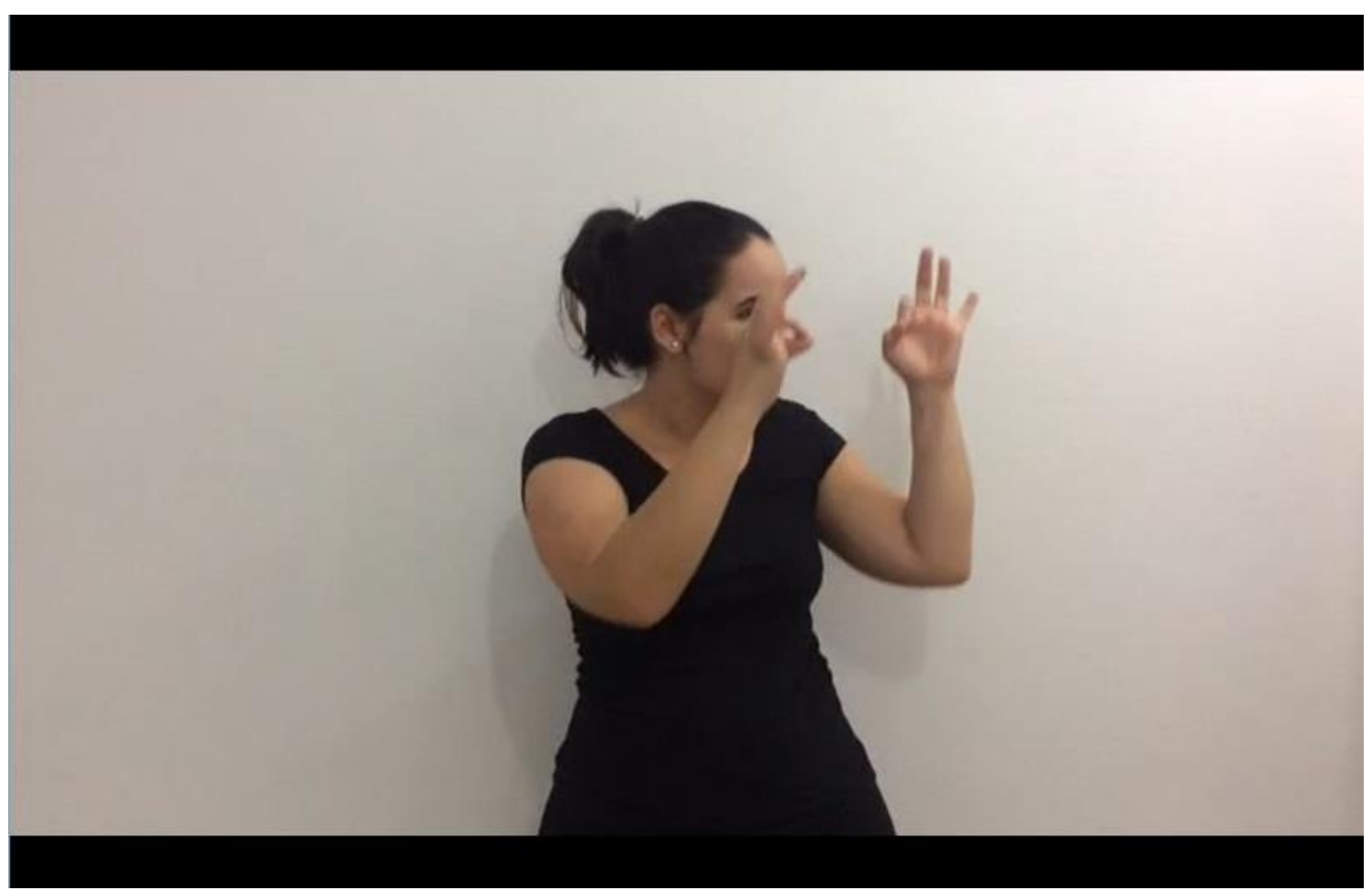

Assim como o movimento de olhos e mãos, alternadamente para a direita e esquerda, indicando o "para lá, para cá", o ato de adormecimento da criança também precisou ser demonstrado. Novamente, priorizou-se o ritmo da poesia, fazendo com que os sinais novamente tivessem uma continuidade. Ou seja, os sinais usados para indicar o "quase adormecimento" da criança surgiram dos sinais utilizados para a criança acordada, brincando e olhando para o movimento do novelo. Além disso, expressões faciais e corporais de sono, adormecimento foram adicionados.

Demonstra-se também a tentativa da criança de permanecer acordada, de continuar a brincadeira. Conseguiu-se isso a partir também do uso de expressões faciais e corporais de resistência, além de movimentos de negação feitos com a cabeça, evidenciando o desejo de não ceder ao sono e permanecer na brincadeira. 
Figura 7 - Há continuidade do uso dos mesmos sinais para "olhos", "movimento de para lá e para cá do novelo", adicionando expressões faciais e corporais e corroborassem com o adormecimento da criança.

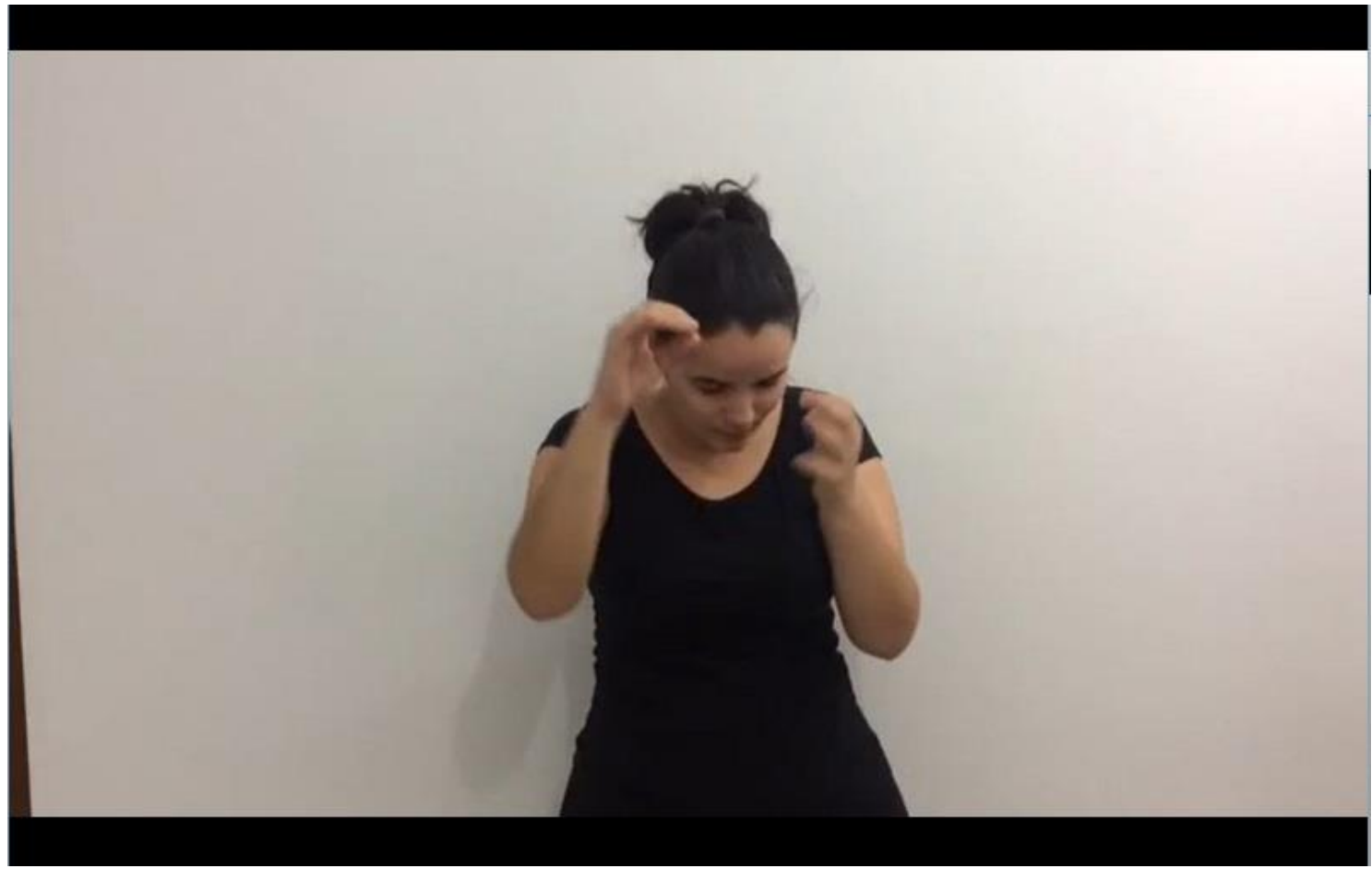

Por último, para encerrar a poesia e mostrar, enfim, que a criança cedeu ao sono e a brincadeira teve curta duração, optou-se por intensificar os movimentos já realizados: o movimento de olhos no esforço de permanecer aberto; o movimento de "para cá, para lá" sendo feito de maneira mais lenta e pouco vigorosa e além dos sinais de sono da criança serem demonstrados de maneira paulatina até o derradeiro vigor, seguidos do acalento sono da criança.

Além disso, mesmo estando subtendido que, uma criança ao brincar com algo na mão e adormecer, naturalmente esse objeto iria cair, escolheu-se demonstrar a queda do novelo, usando o mesmo formato já demonstrado na mão esquerda da imagem 1 , delicadamente sendo derrubada, obedecendo os aspectos físicos do objeto (já que um novelo é leve e não exerce muita pressão ao ser derrubado). As imagens 8 e 9 demonstram estas escolhas. 
Figura 8 - Até o adormecimento da criança, o corpo da tradutora vai se curvando pouco a pouco, demonstrando que foi um processo paulatino.

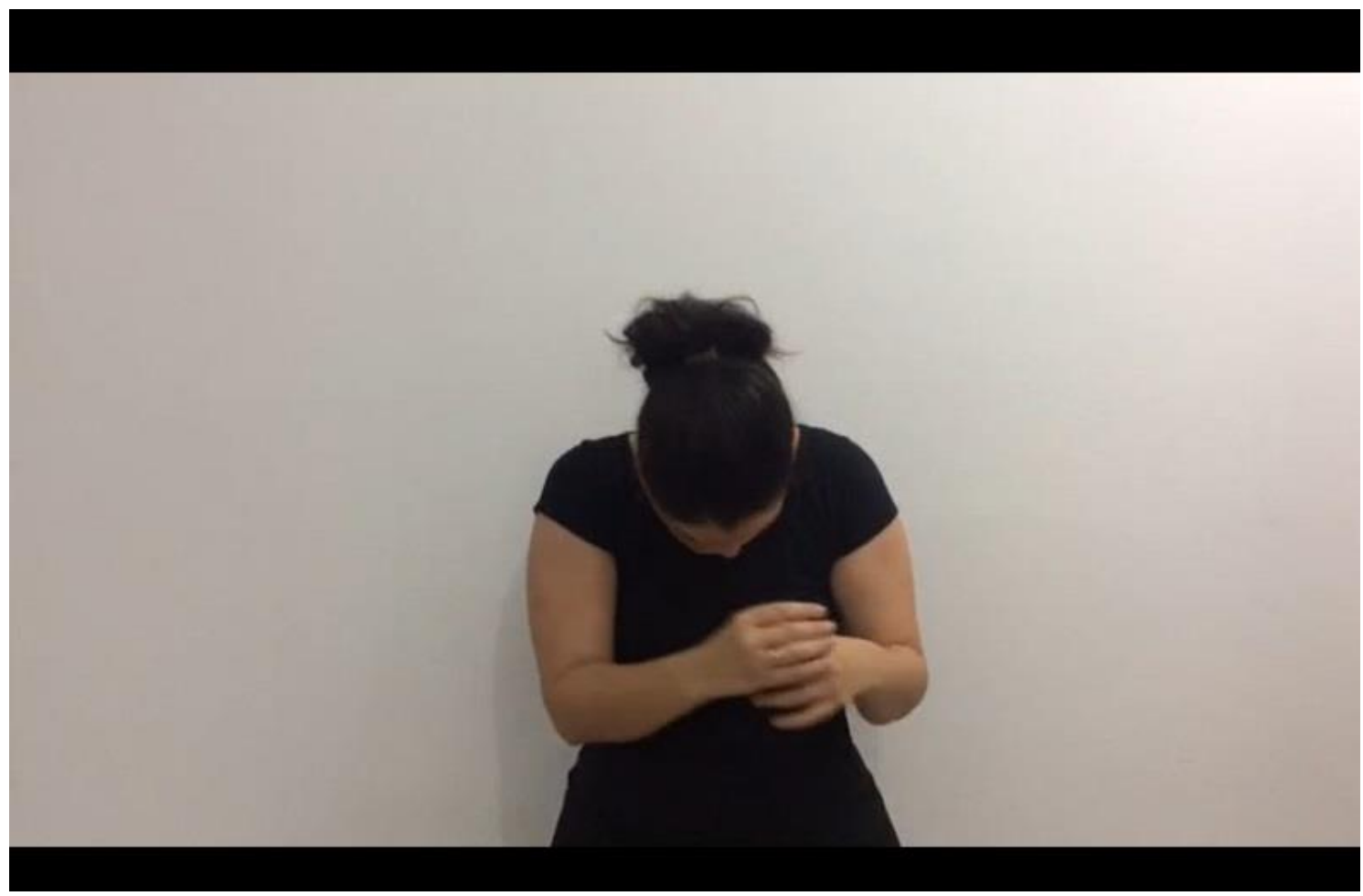

Figura 9 - O ato de derrubar a lã, realizado com a mão esquerda, finalizando a poesia.

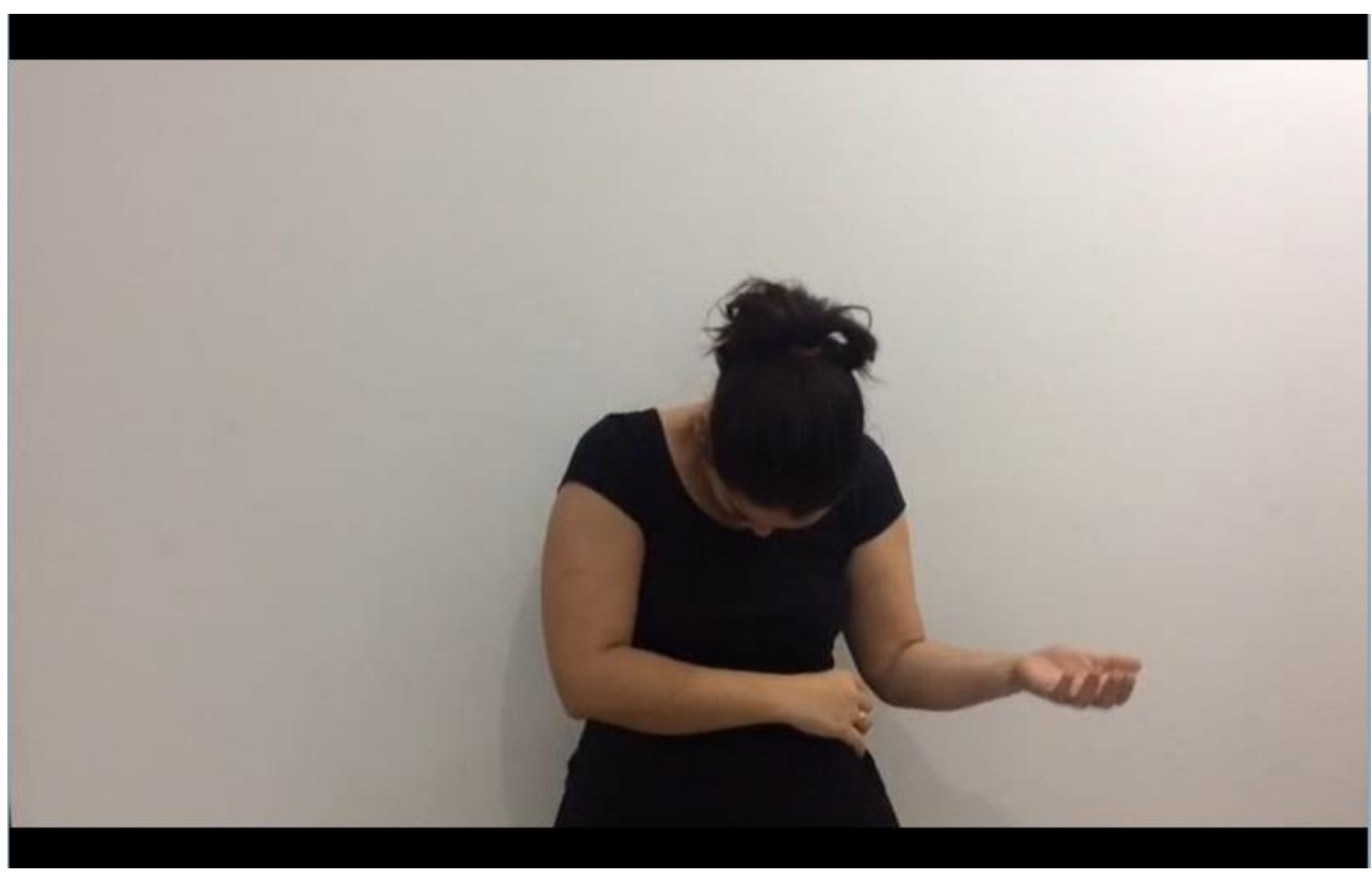

Além das escolhas sinalizadas, outro aspecto importante foi seguir a métrica e a musicalidade do poema. Apesar de nem todo jogo fonético de palavras percebidos na versão da 
poesia na língua portuguesa funcionar na Libras (por serem jogos sonoros, próprios de língua oral e não de língua visual) ${ }^{x i i}$, a tradução tentou o máximo seguir a métrica e a musicalidade dos versos, sendo a sinalização ritmada, continuada, com o objetivo de aflorar emoção e prazer poético a quem vê.

Além do morfismo já citado, também se utilizou o uso de metáforas na tradução, onde novos significados são apropriados a depender do contexto, numa justaposição de ideias que parecem que não tem conexão entre si, mas se fundem poeticamente; a repetição e a simetria e a direção do olhar na movimentação destes classificadores do "para lá e para cá" e no 'derrubar do novelo' garantiram a musicalidade da tradução. Houve algumas adições, substituições, ganhos e perdas para se chegar até esta tradução, a priori, considerada final.

\section{Considerações Finais}

Realizar a tradução do poema Debussy de Manuel Bandeira foi um desafio como tradutora. Naturalmente, no tradutor, há o desejo de se aprimorar cada vez mais a versão final, de fazer escolhas corretas e que mantenham o sentido do texto fonte. Compartilha-se os sentimentos de Nicoloso (2010) ao realizar a tradução do poema "Os Cinco Sentidos", de Paul Scott (da Língua de Sinais Britânica para a Língua Portuguesa escrita): satisfação ao verificar as escolhas feitas, comparadas a "um jogo sedutor e desafiante, a uma aposta tentadora, onde o sujeito envolvido não consegue ou não quer parar" (p.330).

Ressalta-se a complexidade no processo de busca da "equivalência" linguística em línguas de modalidades diferentes. O tradutor acaba se manifestando a partir das escolhas tradutório que faz, sendo dúbia sua "invisibilidade" no texto final, além da "fidelidade" na tradução, principalmente no caso deste estudo, com línguas fonte e alvo de modalidades diferentes (oral e visual-espacial respectivamente). O sentimento no tradutor é o de inacabamento, já que estas considerações finais em nenhum momento sinalizam o fim do processo tradutório e sim, a finalização destas escrituras.

Por último, optou-se por usar, na versão final, imagens que demonstrassem as estratégias de tradução escolhidas. Essas imagens permitem que o público surdo se sinta reconhecido e empoderado no uso de sua língua, além de favorecer o entendimento desta modalidade de tradução desconhecida por uma grande parcela dos ouvintes. Ressalta-se o patamar de língua das Línguas de Sinais, sendo estas também alvos de estudos da Tradução, incentivando novas pesquisas tradutórias no contexto desta língua. 


\section{REFERÊNCIAS BIBLIOGRÁFICAS}

BASSNETT, S. História da tradução literária. In: Estudos da Tradução: Fundamentos de uma disciplina. Tradução de Vivina de Campos Figueiredo. Lisboa: Fundação Calouste Gulbenkian, 2003. p. 75-124.

COSTA, W. GUERINI, A. Colocação e qualidade na poesia traduzida. In: Tradução em Revista, v. 3, p. 1-15, 2006. Disponível em: http://www.maxwell.vrac.puc-rio.br/9358/9358.PDF. Acesso em: 03/08/2015.

FELIPE DE SOUZA, TâniaAmara. A relação sintático-semântica dos verbos e seus argumentos na língua brasileira de sinais (libras). 1998. Tese (Doutorado em linguística) Universidade Federal do Rio de Janeiro, Rio de Janeiro, 1998.

GUERINI, A. “L'Infinito”: tensão entre teoria e prática na tradução de Haroldo de Campos. Cadernos da Tradução, Florianópolis, VI, p, 77-103. Disponível em: https://periodicos.ufsc.br/index.php/traducao/article/view/5684. Acesso em: 03/08/2015

KARNOPP, L, P. Produções culturais em língua brasileira de sinais (Libras). Letras de Hoje, Porto Alegre, v. 48, n. 3, p. 407-413, jul./set. 2013. Disponível em: http://revistaseletronicas.pucrs.br/ojs/index.php/fale/article/view/12616. Acesso em: 03/08/2015.

114 KLAMT. Tradução comentada do poema em língua brasileira de sinais "Voo sobre rio". Belas Infiéis, v. 3, n. 2, p. 107-123, 2014. Disponível em: http://periodicos.unb.br/index.php/belasinfieis/article/view/13009. Acesso em: 03/08/2015.

LARANJEIRA, Mário. Poética da tradução. Do sentido à significância. São Paulo: Editora da Universidade de São Paulo, 2003.

LUCHI, M. Interpretação de descrições imagéticas: onde está o lexico? Dissertação de mestrado. Universidade Federal de Santa Catarina; Florianópolis, 2013.

MCCLEARY, Leland Emerson; VIOTTI, Evani de Carvalh.o. Transcrição de dados de uma língua sinalizada: Um estudo piloto de transcrição de narrativas na língua de sinais brasileira (LSB). In: LIMA-SALLES, H. M. M. (Org.). Bilingüismo dos surdos: Questões lingüísticas e educacionais. Goiânia, GO: Cânone Editorial, 2007, v. , p. 73-96.

NICOLOSO, S. Traduzindo poesia em língua de sinais: uma experiência fascinante de verter gestos em palavras. Cadernos da Tradução, Florianópolis, v. 2, n.26, p. 307-332, 2010. Disponível em: ttps://periodicos.ufsc.br/index.php/traducao/article/viewArticle/15719. Acesso em: 03/08/2015.

QUEIROZ, M. Traduzindo poesia infantil: o relato de uma tradutora-aprendiz. Tradução em Revista, 3, 2006. Disponível em: http://www.maxwell.lambda.ele.puc-rio.br. Acesso em: 03/08/2015.

SCHLEIERMACHER, Friedrich. Sobre os diferentes métodos de tradução. Tradução de Celso R. Braida. In: HEIDERMANN, Werner (Org.). Clássicos da teoria da tradução. Vol. 1, 2a ed. Florianópolis: UFSC/Núcleo de Pesquisa em Literatura e Tradução, 2010. 
SILVA, S. M. Poemas em sinais: Reflexões teóricas acerca do processo de tradução literária. In-Traduções, Florianópolis, v. 4, n. 6, p.42-56, jan./jun., 2012. Disponível em: http://incubadora.periodicos.ufsc.br/index.php/intraducoes/article/view/1841/0. Acesso em: 03/08/2015.

STONE, C., WEST, D., Translation, representation and the Deaf 'voice. Qualitative Research. 2012. Disponível em: sagepu.b.co.uk/journalsPermissions.nav. DOI: 10.1177/1468794111433087. qrj.sagepub.com

STROBEL, K. As imagens do outro sobre a cultura surda. 2. ed. rev. Florianópolis: ed. da UFsC, 2009.

SUTTON-SPENCE, Rachel. Poetry. in: PFAU, Roland.; STEINBACH, Markus; WOLL, Bencie. Sign Language: na international handbook. Berlin-Germany: Walter de Gruyter, 2012. p. 998-1023.

Analyzing Sign Language Poetry.London: Macmillan, 2005.

WEININGER, M., J., SUTTON-SPENCE, R., Quando múltiplos olhares geram diferentes experiências de tradução ao português de um poema em libras: o caso de "Homenagem Santa Maria" de Godinho (2013). Anais do IV Congresso Nacional de Pesquisas em Tradução e Interpretação de Libras e Língua Portuguesa, UFSC, Florianópolis-SC.2014. Disponível em: http://www.researchgate.net/publication/277076912_QUANDO_MLTIPLOS_OLHARES G ERAM DIFERENTES EXPERINCIAS DE TRADUO AO PORTUGUS DE UM POEM A_EM_LIBRAS_O_CĀSO_DE_HOMENAGEM_SANTA_MARIA_DE_GODINHO_\%282 $013 \% 29$. Acesso em 10 de agosto de 2015.

XAVIER, A. N. Variação fonológica na libras: um estudo da alternância no número de articuladores manuais envolvidos na produção dos sinais. In: XVI SETA - Seminários de Teses em Andamento, 2011, Campinas. Anais do SETA (UNICAMP), 2011. v. 5. p. 119-145.

\footnotetext{
${ }^{\text {i }}$ Saionara Figueiredo SANTOS - Professora da área de Tradução, no Instituto Federal de Santa Catarina (IFSC Câmpus Palhoça Bilíngue). Doutoranda em Estudos da Tradução pela Universidade Federal de Santa Catarina (UFSC). Mestre em Educação Ambiental pela Universidade Federal do Rio Grande (2013). Graduada em Tecnologia em Saneamento Ambiental pela Faculdade de Tecnologia Centec (2009). Graduanda em Pedagogia pelo Centro Universitário Paulistano. Disponível em: http://lattes.cnpq.br/1435988679423230. Acesso: junho de 2016.

iiNeste artigo, os surdos mencionados são usuários da Língua Brasileira de Sinais (Libras).

iii Usa-se o termo "línguas de sinais" para delimitar que cada país possui a sua língua de sinais. Esse artigo trata de uma tradução para a língua Brasileira de Sinais, porém, esta pesquisa e outras pesquisas relacionadas à área contribuem para o conjunto dessas línguas.

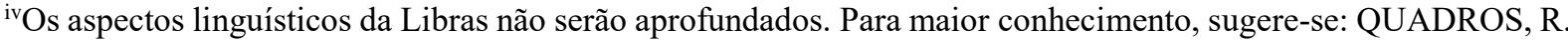
M. de \& KARNOPP, L. Língua de sinais brasileira: estudos lingüísticos. Art Med. 2004.

'Existem algumas traduções de poemas e poesias da Língua de Sinais para a Língua Portuguesa (NICOLOSO, 2010; KLAMT, 2014, por exemplo); porém o foco desse artigo é o processo inverso. Em ambos os sentidos, o número de estudos que detalhem o processo realizado é incipiente.

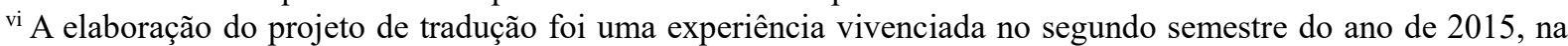
disciplina intensiva de "Práticas em Tradução" ministrada pelo Prof. Dr. Artur Ataíde, oferecida pelo Programa de Pós-Graduação em Estudos da Tradução (PGET) do Centro de Comunicação e Expressão (CCE) da Universidade Federal de Santa Catarina (UFSC).

vii Comunidade surda não é apenas uma comunidade linguística. É onde o surdo consegue usar sua língua de maneira natural, desenvolver sua identidade, valorizando sua cultura e favorecendo a comunicação, permitindo o
} 
senso de pertencimento a uma comunidade que utiliza a mesma língua. Strobel (2009) define Cultura surda como o jeito surdo de entender o mundo e modificá-lo, a partir de suas percepções visuais, que "contribuem para a definição das identidades surdas e das "almas" das comunidades surdas. Isto significa que abrange a língua, as ideias, as crenças, os costumes e os hábitos do povo surdo. [...] o essencial é entendermos que cultura surda é como algo que penetra na pele do povo que participa das comunidades surdas, que compartilha algo que tem em comum, seu conjunto de normas, valores e comportamentos" (STROBEL, 2009, p. 27).

viii Ou seja, por artefatos culturais produzidos em língua de sinais, sem a necessidade de tradução. Para saber mais sobre a literatura surda e poesia surda, indica-se como leitura de "Produções culturais de surdos: análise da literatura surda" de Lodenir Becker Karnopp (2010) e "Narrativa e poesia da língua de sinais", de Rachel SuttonSpence (2005).

ix A Língua de Sinais possui modalidade viso-espacial, enquanto as línguas orais possuem modalidade oralauditivas. No que tange ao registro, o registro de poesias ou de traduções feitas para a Língua de Sinais é feito por vídeo, ao contrário das línguas orais, onde o registro é escrito.

${ }^{x}$ Corrobora-se com Xavier (2011, p. 121) ao explicar sobre Glosa em seu artigo diz: "Na literatura sobre línguas de sinais, os itens lexicais dessas línguas são, em geral, representados graficamente por meio de glosas. Essas glosas consistem de uma ou mais palavras semanticamente equivalentes em uma língua oral e são grafadas em maiúsculo (McCleary e Viotti, 2007). Além disso, como explica Felipe de Souza (1998), utiliza -se o símbolo@ na glosa de um sinal, quando a palavra da língua oral correspondente a ele apresenta alguma marca morfológica referente a gênero. Com isso, captura-se o fato de que no sinal glosado não há distinção entre masculino e feminino. No exemplo em questão, o símbolo@ está no lugar dos morfemas $\{-0\}$ ou $\{-\mathrm{a}\}$ do português.

${ }^{x i}$ Classificadores são estratégias de produção de significado. Luchi (2013), em sua dissertação de mestrado, ao explicar sobre como as descrições imagéticas acontecem em Libras, explica que estas podem ocorrer "pelas Estruturas Altamente Icônicas (EAI) e outra pelo léxico padrão e apontamentos manuais, sendo a segunda algo mais semelhante ao que temos nas línguas orais (PIZZUTO et al. 2006). Cuxac (1996) trabalhou três tipos de transferências: transferências de forma e tamanho, transferências de situação e transferências de pessoa. Com base em Cuxac (1996), Campello (2008) propõe em sua tese que as EAI sejam chamadas de Descrições Imagéticas, também compostas por transferências. Com base nesse estudo, posteriormente, Campello (2008) reformula as três transferências apresentadas por Cuxac e acrescenta duas, totalizando cinco transferências:1)Transferência de Tamanho e de Forma (TTF); 2)Transferência Espacial (TE); 3) Transferência de Localização (TL); 4)Transferência de Movimento (TM) e 5) Transferência de Incorporação (TI)" (p. )Para mais informações sobre descrições imagéticas, recomenda-se a leitura desta dissertação, disponível em: https://repositorio.ufsc.br/bitstream/handle/123456789/106845/322457.pdf?sequence=1 .

xiiPor exemplo, "para cá, para lá, para cá e... O novelozinho caiu".

RECEBIDO EM: 29 de fevereiro de 2016

ACEITO EM: 12 de junho de 2016 